\title{
Regional Variations and Trends in Mortality from Cardiovascular Diseases in Population aged 0-64 in Dalmatia and Slavonia, 1998-2009
}

\author{
Ankica Džono-Boban ${ }^{1}$, Selma Šogorić ${ }^{2}$ and Silvije Vuletić ${ }^{3}$ \\ ${ }^{1}$ Dubrovnik-Neretva County Institut of Public Health, Department of Health Promotion, Dubrovnik, Croatia \\ 2 University of Zagreb, School of Medicine, »Andrija Štampar « School of Public Health, Department of Social Medicine and \\ Organization of Healthcare, Zagreb, Croatia \\ ${ }^{3}$ University of Zagreb, School of Medicine, »Andrija Štampar« School of Public Health, Department of Medical Statistics, \\ Epidemiology and Medical Informatics, Zagreb, Croatia
}

\begin{abstract}
A B S T R A C T
The aim of this paper was to analyse the regional variations and trends in mortality from cardiovascular diseases in the population aged 0-64 years in Dalmatia and Slavonia, over the period 1998 to 2009. Mortality data were derived from Central Bureau of Statistics. The results show that age-standardized mortality rates from total cardiovascular diseases, ischaemic heart diseases and cerebrovascular diseases were lower in Dalmatia than rates for Slavonia, for both genders. All mortality rates, except rates for ischaemic heart diseases mortality for men in both regions, showed the trend of decline. Dalmatia has a more protective factors in pattern of Mediterranean diet. The improvement of cardiovascular health and reduction of premature mortality from cardiovascular diseases requires a system and comprehensive intervention approach at all levels of health care and multisectorial coordination.
\end{abstract}

Key words: mortality, cardiovascular disease, ishaemic heart disease, cerebrovascular disease, regions, Croatia

\section{Introduction}

Cardiovascular diseases (CVD) are the major cause of disability, loss of productivity and premature death throughout the world, and contributes substantially to the escalating costs of health care ${ }^{1}$. Papers, previously published, showed regional variation and differences both in the levels and in the trends in cardiovascular mortality between and within countries in Europe ${ }^{2,3}$. It has reported a clear north-east and south-west gradient in age-standardized mortality from cardiovascular diseases, with lowest rates for both men and women in some Mediterranean countries (France, Spain and Italy) ${ }^{3}$. The spatial variability in cardiovascular mortality may have both research and public health implications since they imply different strategies to improve cardiovascular health at national and regional levels.

CVD is the main cause of death before the age of 65 in Europe and the second main cause of death of same aged-group in the European Union (EU) ${ }^{4}$. In the Mediterranean region of Europe the incidence and mortality of CVD is much lower than in northern Europe, and it has been suggested that this may be due, in part, to dietary factors ${ }^{2,3}$. Recent findings from large European cohort studies sugesst that a high degree of adherence to the Mediterranean diet is associated with a reduction in cardiovascular mortality ${ }^{5-7}$. Despite variations, the Mediterranean diet is characterized typically by the use of olive oil as an important fat source, abundance of fruit and vegetables, legumes, fish, unsaturated fat, wine in low to moderate amounts ${ }^{8}$.

Croatia is heterogeneous country, divided in regions with notable cultural, natural-environmental and social-economic diversities. Eastern region or Slavonia, the continental part of Croatia, and Dalmatia, the costal part, differ by cultural habits, traditions, socio-economic development and agricultural production. These differences have impact on lifestyle patterns and health of the population. Dalmatia traditionally shares the lifestyle of Mediterranean people, including a dietary pattern that is 
characteristic of Mediterranean-style diets. The lifestyle in Eastern continental region resembles that in Central European Countries, in which the nutritional habits are inclined fatty diet with less vegetables intake.

Due to these differences our objective was to analyse trends in mortality from total cardiovascular diseases, ischaemic heart diseases (IHD) and cerebrovascular diseases in the population aged 0-64 years in Dalmatia and Slavonia, and Croatia, as a whole, over the period 1998 to 2009.

\section{Material and Methods}

Mortality data (absolute number of deaths), for period 1998-2009, were derived from Central Bureau of Statistics and covered the age range 0-64 years. Mortality rates were expressed as rate per a population of 100 000 a year and separately for men and women. Population data were obtained from Census 2001. Age-standardization was performed by the direct method using the WHO European population as standard. To reduce random variation in annual mortality rates in the trend figures, rates were averaged for 3 years (1998-2000, 2001-2003, etc).

We used the International Classification of Diseases, 10 th revision (ICD-10), for coding of mortality data ${ }^{9}$. CVD was defined as ICD-10 codes I00-I99, IHD as ICD-10 codes I20-I25 and cerebrovascular diseases as ICD-10 codes I60-I69.

For our analysis, Dalmatia included four counties: Zadar, Šibenik-Knin, Split-Dalmatia and Dubrovnik-Neretva. Slavonia, as Eastern Croatian region, included five counties: Brod-Posavina, Osijek-Baranja, Požega-Slavonija, Virovitica-Podravina and Vukovar-Srijem.

\section{Results}

Figures 1, 2 and 3 show trends in mortality from total CVD, IHD and cerebrovascular diseases in men and women for the age group 0-64 in two Croatian regions, Dalmatia and Slavonia, and Croatia as a whole over the period 1998-2009.

Time trends (1998-2009) in age-standardized mortality rates from cardiovascular diseases showed some differences between Dalmatia and Slavonia.

In Dalmatia, age-standardized mortality rates from CVD, IHD and cerebrovascular diseases were lower compared with Slavonia and Croatia as a whole for both, men and women, while rates for Slavonia were higher than rates for Croatia entire period 1998-2009. All mortality rates for women were lower than rates for men in both regions and Croatia.

A decrease in mortality rates from total CVD was observed in women in both regions; from 39.75/100 000 in 1998-2000 to 26.47 in 2007-2009 (-33.4\%) for Dalmatia respectively from 68.11 in 1998-2000 to 43.93 in 2007- $2009(-35.5 \%)$ for Slavonia (Figure 1). In Slavonia, similar trend was observed for men, decline from
$183.15 / 100000$ in $1998-2000$ to 139.02 in $2007-2009$ $(-24.1 \%)$. By contraries, in Dalmatia decline of age-standardized mortality rates from total CVD for men was recorded from 1998-2000 to 2001-2003, but thereafter mortality rates remained at the same level (Figure 1).

Decline of age-standardized mortality rates from IHD were observed in Dalmatia (-37.0\%) and Slavonia (-21.1\%), for women (Figure 2). These rates for Dalmatia were lower twice than rates for Slavonia. On the contrary, in Dalmatia, the decline of age-standardized mortality rate from IHD was recorded from 1998-2000 to 2001-2003 for men, and thereafter, an increase of these rates was observed from 44.99/100 000 men in 2001-2003 to 47.33/ 100000 in 2007-2009. In Slavonia, age-standardized mortality rates from IHD declined from 81.72/100 000 men in $1998-2000$ to $62.74 / 100000$ in $2004-2006$, but increased thereafter, to reach 70.63/100 000 in 2007-2009.

In Dalmatia, age-standardized mortality rates from cerebrovascular diseases declined for both women and men, from $15.05 / 100000$ in 1998-2000 to 8.74 in 2007$2009(-41.9 \%)$ respectively from 26.96 to 20.02 for men $(-25.8 \%)$ (Figure 3). In Slavonia, age-standardized mortality rates from cerebrovascular diseases declined from 54.36 in $1998-2000$ to 37.84 in $2001-2003$ for men, and thereafter mortality rates didn't changed. In women in

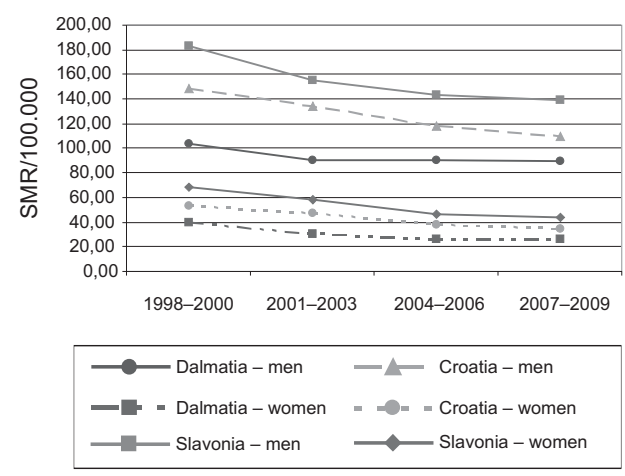

Fig. 1. Trends in age-standardized mortality rates (age group 0-64) from total cardiovascular diseases in Dalmatia, Slavonia and Croatia, 1998-2009.

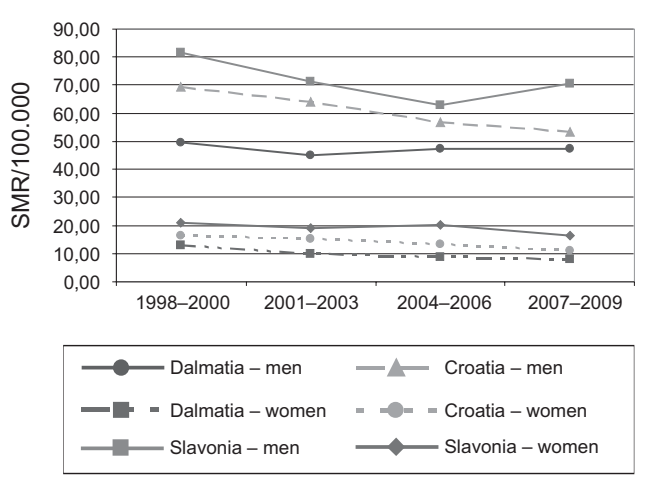

Fig. 2. Trends in age-standardized mortality rates (age group 0-64) from ishaemic heart diseases in Dalmatia, Slavonia and Croatia, 1998-2009. 


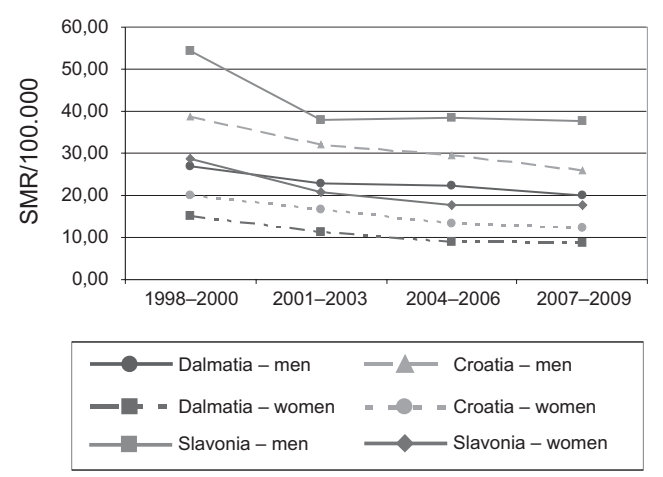

Fig. 3. Trends in age-standardized mortality rates (age group 0-64) from cerebrovascular diseases in Dalmatia, Slavonia and Croatia, 1998-2009.

Slavonia, the pattern was similar, with decreasing trend from 1998-2000 to 2004-2006, and subsequently no change was recorded.

\section{Discussion}

The results of the present analysis show that age-standardized mortality rates from total CVD, IHD and cerebrovascular diseases were lower in Dalmatia than rates for Slavonia and Croatia, as a whole, for both, men and women aged 0-65 years over the period 1998-2009. All mortality rates, except rates for IHD mortality for men in both regions, show the trend of decline. The mortality differences between these two Croatian regions can be explained by geographical and environmental characteristics, differences in cultural habits and socio-economic level, differences in the prevalence of cardiovascular risk factors, as well as differences in the health care. According to the results from Croatian Adult Health Survey, conducted 2003, the prevalence of cardiovascular risk burden (CVRB) (high, moderate and low burden) was higher in Slavonia in both genders, men $(90.6 \%)$ and women $(86.7 \%)$, than in Coastal region ${ }^{10}$. On the contrary, Coastal region showed the highest prevalence of no CVRB in both, men (12.2\%) and women (18.8\%).

A combination of several risk factors are responsible for $\mathrm{CVRB}^{11}$. A key role has a dietary pattern which is important factor in the promotion and maintenance of good health throughout the entire life course ${ }^{6,7}$. Culturologically and agriculturally influence on the dietary pattern explains the different dietary habits in these two regions. Dalmatia, as the coastal region of Croatia, has the characteristics of the Mediterranean nutrition, and Slavonia, as the continental region, has a dietary pattern, named "Western diet «, with the large intake of dried and red meat and animal fat ${ }^{12}$. The highest prevalence of unhealthy dietary habits in both genders was recorded in Slavonia, and healthier dietary habits were observed in population of Coastal region ${ }^{13}$. Geographical variations across Europe have been investigated in many studies comparing dietary patterns between northern and southern European populations. A north-south gradient in diet quality has been described, with a higher intake of energy-dense foods by northern European populations, whereas southern populations are more likely intake to adherence a Mediterranean-style diet ${ }^{14-18}$. The »Western diet « as a cardiovascukar risk factor respectively the protective effect of the Mediterranean diet for development of caridovascular diseases and the realtionship between these observed dietary patterns and cardivascular mortality was published. The Mediterranean countries have lower mortality from CVD than a continental countries which is explained by lifestyle paterrns and dietary habits in Mediterranean countries in comparison with other regions of Europe ${ }^{7,19-23}$. The Mediterranean diet was associated with a significant reduction of cardiovascular incidence and mortality ${ }^{7,24}$. The changes of fat consumption, decline intake of saturated fat and increase intake of polyunsaturated fat, have explaned changes related to the decline in IHD mortality within many European countries respectively replacement of saturated with monounsaturated lipids is associated with a considerable reduction in coronary heart disease risk ${ }^{25-27}$.

Higher prevalence of smoking and higher prevalence of unhealthy dietary habits, observed among male population in both regions, may be responsible for mortality differences between genders in both regions (all mortality rates were higher in men than in women). The results of few cohort studies have shown that the differences in total CVD and IHD mortality can be explained by high prevalence of smokers combination with high saturated fat intake and low intake of antioxidants ${ }^{28,29}$.

Hypertension, as the cardiovascular risk factor, can results in myocardial infarction, stroke, congestive heart failure, and finally sudden cardiac deaths ${ }^{11}$. However, the results from CAHS showed the higher prevalence of arterial hypertension in male population in Dalmatia compared with Slavonia, the mortality rates from IHD and cerebrovascular diseases, observed in this study, were lower in Dalmatia. This results can be explained by the higher prevalence of arterial hypertension with presence of additional risk factors, which is in accordance with previous research results ${ }^{30-32}$. Among persons with hypertension, the coronary events are attributable to the presence of two and more additional risk factors ${ }^{30}$. CVD mortality rates increased in hypertensive men in the presence of additional risk factors; a 5-fold increase in the group with 1 to 2 additional risk factors and a 15-fold increase in the group with more than two additional risk factors $^{31}$. On the other hand, only $14 \%$ of coronary events in hypertensive men and $5 \%$ of coronary events in hypertensive women occurred in the absence of additional risk factors ${ }^{30}$. Additionally, among hypertensive men and women, the higher prevalence persons who consume fruit and vegetable everyday was recorded in Dalmatia in both gender. These healthy habits among population in Dalmatia could bi explanation for the differences between mortality rates from CVD, especially from IHD mortality, in these two regions. The basic components of the Mediterranean diet, fruit, vegetables and olive oil, are mainly responsible for the apparent protection against hypertension $^{7,33}$. The recent meta-analysis of published cohort 
prospective studies, that investigated the effects of adherence to the Mediterranean diet on health status, showed that the Mediterranean diet was associated with a significant reduction of cardiovascular incidence and mortality ${ }^{5,7,23,24,34}$. There are several mechanisms by which these protective effects may be mediated, involving antioxidants and other micronutrients, such as flavonoids, carotenoids, vitamin $\mathrm{C}$ and folic acid, as well as dietary fibre $^{7,33,34}$.

Based on currently available research data, one possible explanation for observed cardiovascular mortality differences between Dalmatia and Slavonia could be effects of war (1991-1995) and postwar stress on acute and chronic IHD ${ }^{35}$

Changes in trend may also be due to changes in diagnosis and treatment methods, in recording of disease, or to combination of these factors. Unfortunately, the comprehensive system for cardiovascular disease prevention and interventions does not exist ${ }^{36}$. The implementation of the specific program (check-ups) for the population over 50 years for cardiovascular disease risks does not function according expectation ${ }^{37}$. The Finish results of the comprehensive strategy, that actively promotes primary and secondary prevention programs, showed that the coronary heart disease mortality rates declined by $63 \%$, and accordingly risk factors reduction explained $53-72 \%$ of the mortality reduction and improved treatments approximately $23 \%{ }^{38}$. An analysis of the decline in IHD mortality in the USA showed that $63 \%$ of the decline in the ten-years period could be ascribed to lowering of risk factors (primary and secondary prevention) and $31 \%$ to medical interventions ${ }^{39}$. A similar analysis, conducted in the UK, suggested that about $60 \%$ of the fall in CHD mortality registered in the past two decades can be attributed to declines in major risk factors and $40 \%$ to medical treatment ${ }^{40}$. These facts provide a valuable argument for health policy and strategic planning for improvement cardiovascular health of population.

In conclusion, our analysis shows the cardiovascular mortality differences for the population aged 0-64 between two Croatian regions, continental Slavonia and coastal Dalmatia, with the lower all mortality rates in Dalmatia in both genders. These results suggest that Dalmatia has a more protecitve factors despite high prevalence of some risky life behaviour. The total risk of developing CVD and the high rates from premature deaths from CVD are determined by the combined effect of cardiovascular risk factors, which commonly coexist and act multiplicatively. Anyway, the health of population is seriously disturbed in both regions and it's required emergent, system approach and comprehensive intervention at the primary, secondary and tertiary level of health care as much as at the level of multisectorial coordination. Promoting healthy lifestyles to improve cardiovascular health and to reduce the premature mortality from cardiovascular diseases requires a multisectoral approach involving the various relevant sectors in societies. The national and regional public health intervention model need to be based on the already known cost-effective prevention strategies, and already available scientific and economic information, evidence and research for guiding policy decisions.

\section{R E F E R E N C E S}

1. LEAL J, LUENGO-FERNÁNDEZ R, GRAY A, PETERSON S, RAYNER M, Eur Heart J, 27 (2006) 1610. — 2. KESTELOOT H, SANS S, KROMHOUT D, Eur Heart J, 27 (2006) 107. - 3. MÜLLER-NORDHORN J, BINTING S, ROLL S, WILLICH SN, Eur Heart J, 29 (2008) 1316. — 4. ALLENDER S, SCARBOROUGH P, PETO V, RAYNER M, LEAL J, LUENGO-FERNÁNDEZ R, GRAY A, European Cardiovascular Disease Statistics 2008, accessed 16.05.2011. Available from: URL: http://www. heartstats.org/temp/ESspweb08spchapter.1.pdf. — 5. TRICHOPOULOU A, COSTACOU T, BAMIA C, TRICHOPOULOS D, N Engl J Med, 348 (2003) 2599 - 6. KNOOPS KTB, DE GROOT LCPG, KROMHOUT D PERRIN AE, MOREIRAS-VARELA O, MENOTTI A, VAN STAVEREN WA, JAMA, 292 (2004) 1433. - 7. SOFI F, CESARI F, ABBATE R, GENSINI GF, CASINI A, BMJ, 337 (2008) a1344. - 8. WILLETT WC, SACKS F, TRICHOPOULOU A, DRESCHER G, FERRO-LUZZI A, HELSING E, TRICHOPOULOS D, Am J Clin Nutr, 61 (1995) 1402S. — 9. CROATIAN NATIONAL INSTITUTE OF PUBLIC HEALTH: International Classification of Diseases and Realted Health Problems. Volume 1. 10th revision. (Zagreb, 1994). - 10. KERN J, POLAS̆EK O, MUSIĆ MILANOVIĆ S, DŽAKULA A, FIŠTER K, STRNAD M, IVANKOVIĆ D, VULETIĆ S, Coll Antropol, 33 Suppl (2009) 11. — 11. WORLD HEALTH ORGANIZATION Global heatlh risks: mortality and burden of disease attributable to selected major risks. (WHO, Geneva, 2009), accessed 16.05.2011. Available from URL: http://www.who.int/healthinfo/global_burden_disease/Globa HealthRisks_report full.pdf. - 12. TUREK S, RÜDAN I, SMOLEJ-NARANČIĆ N, SZIROVICZA L, ČUBRILO-TUREK M, ŽERJAVIĆ-HRABAK V, RAK-KAIĆ A, VRHOVSKI-HEBRANG D, PREBEG Ž, LJUBIČIĆ M, JANIĆIJEVIĆ B, RUDAN P, Coll Antropol, 25 Suppl 1 (2001) 77. 13. DOKO JELINIĆ J, PUCARIN-CVETKOVIĆ J, NOLA IA, SENTA A MILOŠEVIĆ M, KERN J, Coll Antropol, 33 Suppl 1 (2009) 31. - 14 HOLDSWORTH M, GERBER M, HASLAM C, SCALI J, BEARDSWORTH A, AVALLONE MH, SHERRATT E, Eur J Clin Nutr, 54 (2000) 530. - 15. PERRIN AE, SIMON C, HEDELIN G, ARVEILER D, SCHAF-
FER P, SCHLIENGER JL, Eur J Clin Nutr, 56 (2002) 393. — 16. HU FB, RIMM EB, STAMPFER MJ, ASCHERIO A, SPIEGELMAN D, WILLETT WC, Am J Clin Nutr, 72 (2000) 912. - 17. PERRIN AE, DALLONGEVILLE J, DUCIMETIÉRE P, RUIDAVETS JB, SCHLIENGER JL, ARVEILER D, SIMON C, Br J Nutr, 93 (2005) 109. — 18. OLIVEIRA A, RODRÍGUEZ-ARTALEJO F, GAIO R, SANTOS AC, RAMOS E, LOPES C, J Am Diet Assoc, 111 (2011) 241. - 19. IESTRA JA, KROMHOUT D, VAN DER SCHOUW JT, GROBBEE DE, BOSHUIZEN HC, VAN STAVEREN WA, Circulation, 112 (2005) 924. - 20. ESTRUCH R, MARTINEZ-GONZÁLEZ MA, CORELLA D, SALAS-SALVADO J, RUIZ-GUTIÉRREZ V, COVAS AI, FIOL M, GÓMEZ-GRACIA E, LÓPEZ-SABATER MC, VINYOLES E, ARÓS F, CONDE M, LAHOZ C, LAPETRA J, SÁEZ G, ROS E, Ann Intern Med, 145 (2006) 1. - 21. SERRA-MAJEM L, ROMAN B, ESTRUCH R, Nutr Rev, 64 (2006) S27. - 22. DAUCHET L, AMOUYEL P, HERCBERG S, DALLONGEVILLE J, J Nutr, 136 (2006) 2588. - 23. FUNG TT, REXRODE KM, MANTZOROS CS, MANSON JE, WILLETT WC, HU FB, Circulation, 119 (2009) 1093. - 24. SOFI F, ABBATE R, GENSINI GF, CASINI A, Am J Clin Nutr, 92 (2010) 1189. 25. PUSKA P, HELASOJA V, PRÄTTÄLÄ R, KASMEL A, KLUMBIENE J, Eur J Public Health, 13 (2003) 11. - 26. UNAL B, CRITCHLEY JA, CAPEWELL S, Circulation, 109 (2004) 1101 - 27. ZATONSKI WA, WILLETT W, BMJ, 331 (2005) 1847. — 28. KROMHOUT D, BLOEMBERG B, FESKENS E, MENOTTI A, NISSINEN A, for the Seven Countries Study Group, Int J Epidemiol, 29 (2000) 260. - 29. HUXLEY RR, NEIL HAW, Eur J Clin Nutr, 57 (2003) 904. — 30. KANELL WB, Am J Hypertens, 13(pt 2) (2000) 3S. - 31. THOMAS F, RUDNICHI A, BACRI AM, BEAN K, GUIZE L, BENETOS A, Hypertension, 37 (2001) 1256. - 32. THOMAS F, BEAN K, PANNIER B, OPPERT J, GUIZE L, BENETOS A, Hypertension, 46 (2005) 654. - 33. PSALTOPOULOU T, NASKA A, ORFANOS P, TRICHOPOULOS D, MOUNTOKALAKIS T, TRICHOPOULOU A, Am J Clin Nutr 80 (2004) 1012. — 34. TRICHOPOULOU A, BAMIA C, TRICHOPOULOS D, BMJ, 338 (2009) b2337. — 35. BERGOVEC 
M, HEIM I, VASILJ I, JEMBREK-GOSTOVIĆ M, BERGOVEC M, STRNAD M, Mil Med, 170 (2005) 431. - 36. DŽAKULA A, ŠOGORIĆ S, POLAŠEK O, JURIŠA A, ANDRIĆ A, RADAKOVIĆ N, TODOROVIĆ G, Col Antropol 33 (2009) 87. - 37. PRISTAŠ I, ERCEG M, STEVANOVIĆ R, RODIN U, (Croatian National Institut of Public Health, Zagreb, 2010), accessed: 20.06.2011. Available from URL: http://www.hzjz.hr/publikaci- je/preventivni 50 09.pdf. - 38. LAATIKAINEN T, CRITCHLEY J, VARTIAINEN E, SALOMA V, KETONEN M, CAPEWELL S, Am J Epidemiol, 162 (2005) 764. - 39. HUNINK MG, GOLDMAN L, TOSTESON AN, MITTELMAN MA, GOLDMAN PA, WILLIAMS LW, TSEVAT J, WEINSTEIN MC, JAMA, 277 (1997) 535. — 40. UNAL B, CRITCHLEY JA, CAPEWELL S. BMJ, 331 (2005) 614.

\section{A. Džono-Boban}

Dubrovnik-Neretva County Institut of Public Health, Department of Health Promotion, Dr. A. Šercera 4a, pp 58, 20001 Dubrovnik, Croatia

e-mail: ankica.dzono-boban@zzjzdnz.hr

\section{REGIONALNE RAZLIKE I TRENDOVI U SMRTNOSTI OD KARDIOVASKULARNIH BOLESTI U POPULACIJI 0-64 GODINE U DALMACIJI I SLAVONIJI, 1998-2009}

\section{S A Ž E T A K}

Cilj ovog rada bio je analizirati regionalne razlike i trendove smrtnosti od kardiovaskularnih bolesti u populaciji 0-64 godine u Dalmaciji i Slavoniji u razdoblju od 1998. do 2009. godine. Podaci o umrlima dobiveni su iz Državnog zavoda za statistiku. Rezultati pokazuju da su dobno standardizirane stope smrtnosti od kardiovaskularnih bolesti ukupno, ishemijskih bolesti srca i cerebrovaskularnih bolesti bile niže u Dalmaciji za oba spola. Sve analizirane stope, osim stopa smrtnosti od ishemijskih bolesti srca za muškarce u obje regije, pokazale su trend smanjenja. Dalmacija ima više zaštitnih kardiovaskularnih čimbenika u modelu mediteranskog načina prehrane. Za unapređenje kardiovaskularnog zdravlja i smanjenja prijevremene smrtnosti od kardiovaskularnih bolesti potreban je sustavan sveobuhvatan intervencijski pristup na svim razinama zdravstvene zaštite i multisektorske suradnje. 